Abstracta Iranica Abstracta Iranica

Revue bibliographique pour le domaine irano-aryen

Volume 30 | 2010

Comptes rendus des publications de 2007

\title{
The Tylos Period Burials in Bahrain. Vol. 1 : The Glass and the Pottery Vessels. 262 p., 626 fig.
}

\section{Rémy Boucharlat}

\section{(2) OpenEdition}

1 Journals

\section{Édition électronique}

URL : http://journals.openedition.org/abstractairanica/37703

DOI : 10.4000/abstractairanica.37703

ISSN : 1961-960X

Éditeur :

CNRS (UMR 7528 Mondes iraniens et indiens), Éditions de l'IFRI

\section{Édition imprimée}

Date de publication : 8 avril 2010

ISSN : 0240-8910

\section{Référence électronique}

Rémy Boucharlat, «The Tylos Period Burials in Bahrain. Vol. 1 : The Glass and the Pottery Vessels 262 p., 626 fig. », Abstracta Iranica [En ligne], Volume 30 | 2010, document 102, mis en ligne le 08 avril 2010, consulté le 26 septembre 2020. URL : http://journals.openedition.org/abstractairanica/37703 DOI : https://doi.org/10.4000/abstractairanica.37703

Ce document a été généré automatiquement le 26 septembre 2020.

Tous droits réservés 


\title{
The Tylos Period Burials in Bahrain. Vol. 1 : The Glass and the Pottery Vessels. 262 p., 626 fig.
}

\author{
Rémy Boucharlat
}

1 A Bahrain, la période Tylos, nom de l'île à l'époque séleucide, correspond aux phases archéologiques depuis le IV $\mathrm{e}$ s. av. J.-C. jusqu'à l'arrivée de l'islam. La modernisation du pays a provoqué la fouille de plusieurs nécropoles, plus nombreuses que les sites d'habitat. L'A. a entrepris de rassembler toutes les données disponibles sur les récipients en verre et en poterie de ces périodes. Il en a établi un catalogue très organisé et clair. Cette étude est signalée ici car elle servira désormais de référence pour les périodes considérées, à côté des travaux du même niveau ou souvent moins importants conduits sur la verrerie et la céramique à Dura Europos et Tell Mahuz en Mésopotamie du nord, Séleucie dans le sud, l'île de Failaka (Koweit) et le site côtier d'Ed Dur près du détroit d'Ormuz. Elle sera en particulier précieuse pour les archéologues travaillant dans le sud et sud-ouest de l'Iran et le long de la côte du golfe Persique.

\section{INDEX}

Thèmes : 3.2.3. Séleucides, Parthes et Sassanides 
AUTEURS

RÉMY BOUCHARLAT

CNRS - Lyon 